\title{
The Contribution of Cultural Art in Creating Liong Ornament on the Roof of Tay Kak Sie Temple in Semarang Central Java
}

\author{
Khairul Mustaqin \\ Institut Seni Budaya Indonesia (ISBI) Bandung \\ Jalan Buah Batu No. 212 Bandung
}

\begin{abstract}
The creation of Liong ornaments on the roof of Tay Kak Sie Temple in Semarang Central Java is influenced by various factors of art and cultural aspects. The purpose of this study is to provide an explanation of Liong ornament forms on the roof of Tay Kak Sie Temple; its artistic elements; and cultural art contributions in creating the ornaments. This research uses a qualitative method with a case study. The research found out that ornaments of Liong statue on the roof of Tay Kak Sie Temple have a three-dimensional work with simplification and deformation techniques. Liong statue ornament is an imitative form of animal Chinese mythology. The textures of the ornament are smooth, smooth wavy, and rough. Liong ornaments use seven colours and contain elements of blue monochromatic colour, and they are included in imitative artwork with naturalist's expression style. The ornaments express anger, ambition, and firmness. Furthermore, the forms of ornaments are influenced by several factors including artists, culture, the influence of its origin from the Ming Dynasty, the location of the temple, and belief.
\end{abstract}

Keywords: contribution, cultural art, creation, Liong ornament, temple

\section{INTRODUCTION}

In Central Java, especially in Semarang, there are some historical temples, and one of them is Tay Kak Sie Temple. It is located in the northern coastal area of Java. It is the main temple for 10 temples in Chinatown (Pekojan area), Semarang. The temple building is always closely related to the ornaments in it. One form of the ornament is the statue of Liong. In general, the most prominent temple ornaments are Liong on the roof of the building temple. For Chinese, the Liong is a mythological animal considered to have life value.

The approach using in this study employs the elements of art to examine Liong's ornamentation in the form of the statue. In the art studies, there are several definitions of sculpture. According to Yanarko (2012: 8-9), the definition of the statue can be divided into three, namely imitative, deformative, and non-figurative style. Imitative style (realist/representative) is an artificial statue style of natural forms such as humans, animals, and plants. The deformative style is the style of sculpture which has a lot of changes in its shape compared to its imitation of nature. The non-figurative (abstract) style is the style of sculpture which has generally abandoned its natural forms.

The sculpture is closely related to terms of shape, texture, position, colour, style, and expression. Here are some definitions related to those terms. The word "form" in visual art is defined as a manifestly visible form. Shapes are often referred to figures, 
or forms, such as human and animal forms. There is also a presented form without any purpose, called a shape, which is usually used with the word form or body. The meaning of texture according to Sahman (1993) is the quality of touch from an object surface, which has a real and pseudo touch of the surface. According to Susanto (2011: 48), the barik can also be interpreted as a texture, a touch value, a surface quality of an object. While the colour according to Susanto (2011: 433) is a vibration or wave that is acceptable to the human vision coming from the light through an object. The style, according to Myers in Gie (1996: 10), is a way that creates something unique for its creator as exposed in its sense of creation. Expression, according to Sumantra (2010: 1 ), is the expression of taste, thoughts, ideas, fantasies, and so forth.

Liong's ornament on the roof of Tay Kak Sie Temple is very aesthetics because it has different elements of art, a distinctive character, and an interesting creation background. It is necessary to be revealed, studied, described, and documented more deeply. This research has been carried out to explore how Liong ornaments on the roof of Tay Kak Sie Temple have interesting artistic and influence effect of creation.

\section{METHOD}

This research uses a qualitative research method with a case study. Qualitative research observes human phenomena in their environment, interacts with them, and tries to understand their interpretive words about their surrounding world (Nasution, 1996: 5). A case study is an exploration of a case through in-depth data collection and involves multiple sources of information in a specific context. The focus of case study in this research is a Liong ornament on the roof of Tay Kak Sie Temple Semarang Central Java. This research also uses empirical basis, by understanding and seeing the subject as a work of art.
The object of the research is Liong ornament on the roof of Tay Kak Sie Temple Semarang Central Java. The data is obtained from informants, pictures and photos, documents, and notes. The data collection techniques are conducted by observation, interviews, reading written data and docu-ments. The location of the research is in Tay Kak Sie Temple, Gang Lombok No. 62 Pecinan, Semarang, Central Java. Interviews to obtain information on the history of Tay Kak Sie Temple and Liong's ornaments are conducted directly to informants at the research sites, among others: Thio Tiong Gie (former publicist of Tay Kak Sie Temple); Gan Kok Hwie (chairman of Makin Semarang); and Kwa Tong Hay (Tay Kak Sie Temple publicist). The written data collection is collected through books, literature, records, articles and reports related to the problems being solved. The process of data analysis is conducted in qualitative analysis method through three steps, namely data reduction, data presentation,

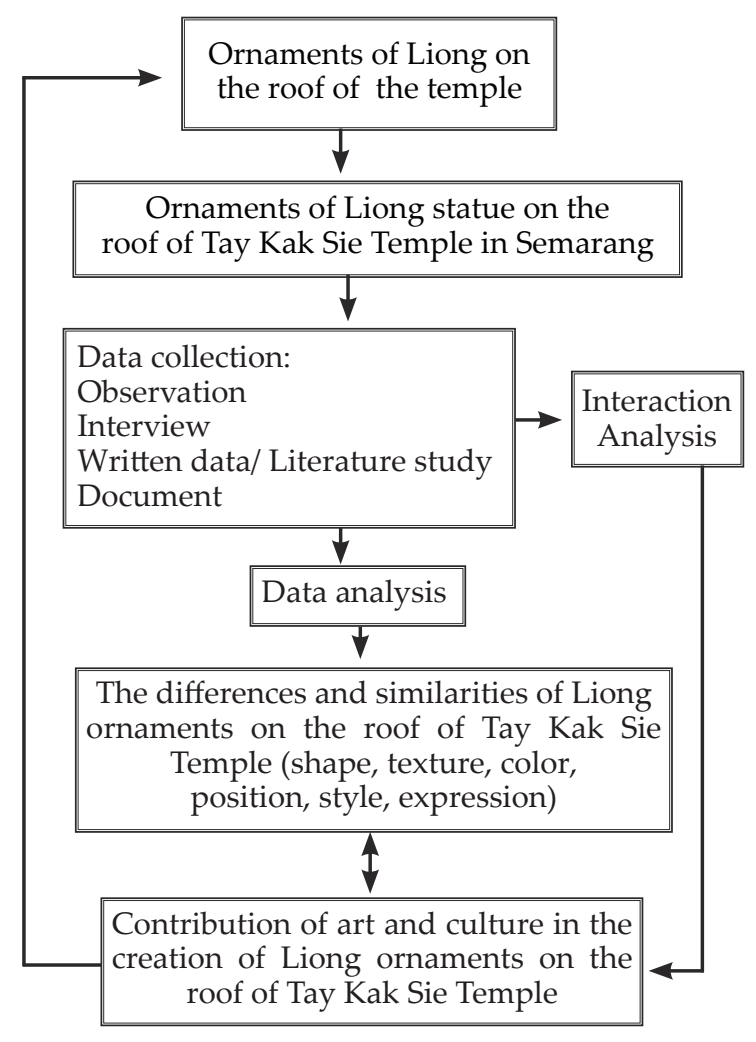

Scheme 1: the flow of research method 
and conclusion. The flow of the research method appears in the Scheme 1.

\section{RESULTS AND DISCUSSION Tay Kak Sie Temple}

Tay Kak Sie Temple is one of 10 temples in Semarang, Central Java. It is located in Gang Lombok no. 62 Semarang. It was established in 1771 and became one of the oldest temples in Semarang. Its building area is approximately $35.8 \times 26.75 \mathrm{~m}^{2}$ with spatial divisions, namely: 1) a front yard; 2 ) a terrace; 3) a waiting room; 4) Impluvium or Inner Court; 5) the main altar; 6) the small altar; 7) room fixtures; 8) storage room/warehouse; 9) toilet; and 10) the front room.

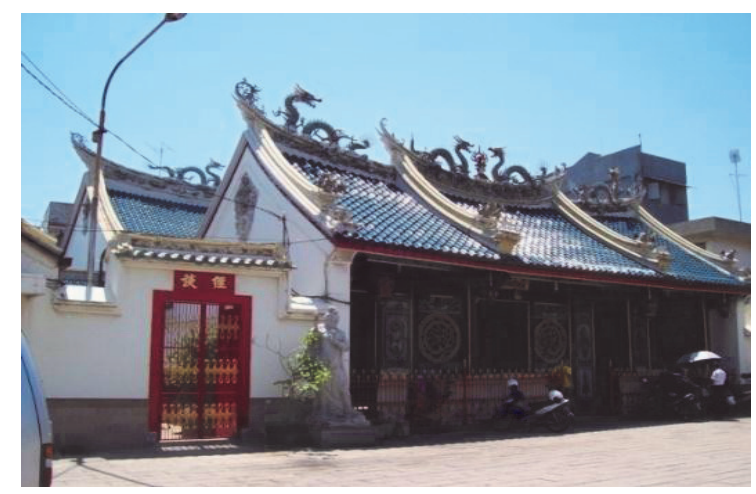

Pic. 1. The temple of Tay Kak Sie, at Gang Lombok No. 62, Semarang. (Documentation: Khairul Mustaqin, 2014)

\section{Liong Ornaments on the Roof of Tay Kak Sie Temple}

Ornaments of Liong statue on the roof of Tay Kak Sie Temple has three-dimensional shapes. Each is about three meters long. Liong's body size is approximately 30 $\mathrm{cm}$. The statue of Liong stands on the foundation of cast cement about $20 \mathrm{~cm}$ thick in its chest and hips. The cast cement at once describes as the cloud.

There are three parts of Liong ornament textures on the roof of Tay Kak Sie Temple, namely smooth, smooth wavy, and rough. Smooth texture is seen on Liong's face surface; smooth wavy texture is on the abdominal surface; while the rough texture is visible on the surface of both the scales and the back. In both Liong, the only different part is the facial colours; the colour of Liong statue on the right side is blue, while the Liong on the left side is light green. Horn is coloured yellow ivory. Nose, tongue, and mouth are red. Scales of the body, from the neck to the tail are coloured light greenish. The stomach is in light yellow colour. The hair clumps at the base of four legs are in red. Claw nails and bony bumps along the dorsal fin are white. The style of Liong ornaments on the roof of Tay Kak Sie Temple is classified as imitative one, that is an imitation of Chinese mythology animal with camel-headed, deer-horned, rabbit-eyed, cow-eared, snake-necked, frog-pouted, fish-scaled, tiger limbs and eagle clawed.

The expression of Liong on the roof of Tay Kak Sie Temple is exposed to the mouth, body, and claws, which exudes strength. The mouth of Liong is opened and grinned with a tongue protruding as if it were roaring. Upper and lower jaws adorned with sharp teeth express anger. The body of Liong is made to wriggling like a wave, expressing the battle of two Liong over the magic jewel.

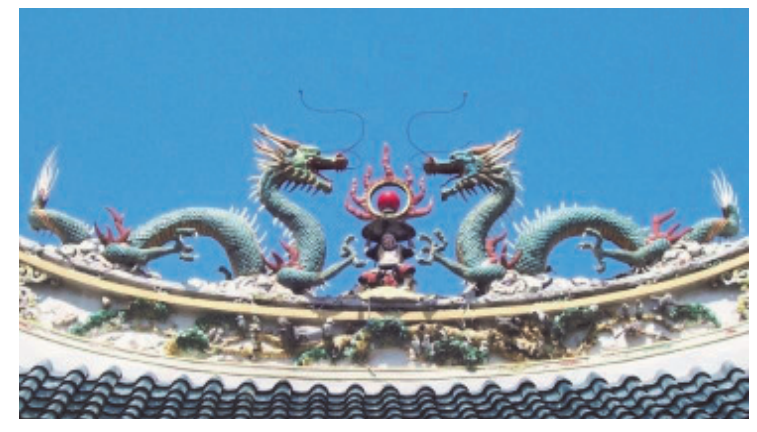

Pic 2. Ornaments of Liong statue on the roof of Tay Kak Sie Temple.

(Documentation: Khairul Mustaqin, 2014)

\section{Artistic Elements on Liong Statue Ornament on the roof of Tay Kak Sie Temple}

The differences among the Liong ornaments on the roof of Tay Kak Sie Temple can be studied according to the elements of form, texture, colour, position, style, and 
expression. The shape of Liong statue ornament on the roof of Tay Kak Sie Temple is the only ornament with the positions of both statues closely face to face with each other. Structurally, Liong's body extends from the chest to the tail; chest stands upright; the head looks straight ahead. The hips and the chest attach to the ridge of the roof.

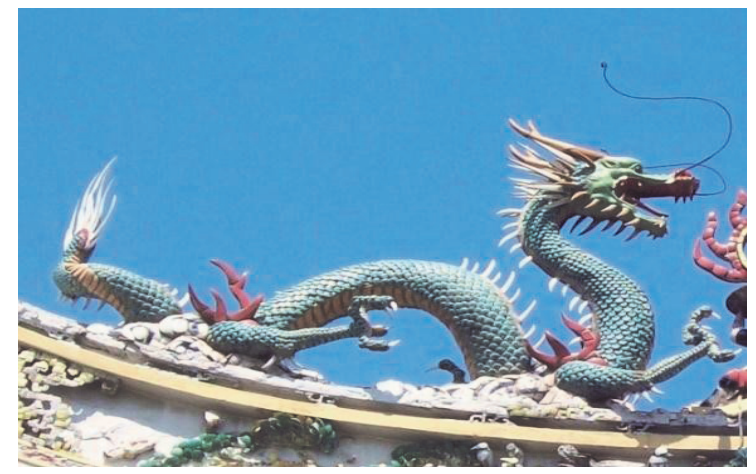

Pic. 3. The form of Liong statue ornament on the roof of Tay Kak Sie Temple

(Documentation: Khairul Mustaqin, 2014)

The form of Liong statue on the roof of Tay Kak Sie Temple appears to have a soul and characters. Long and twisting body shapes make it seemingly move. The upright chest makes it sturdy and strong. The shape of the upright head reveals a fierce and alert nature.

From the picture above, it can be read that Liong statue on the roof of Tay Kak Sie Temple has its own characteristics. Its peculiarity lies in the direction of the two statues facing frontally toward its opponent, with the chest standing straight, and the head staring straight ahead toward the opponent in front of him. It also has materials with a different surface texture. The Texture is divided into three parts, namely: fine texture, smooth corrugated texture, and coarse texture.

The texture of smooth surface appears on the face of Liong. It is made flat, equal and it is refined so it looks slick like the face surface. The smooth wavy texture appears on the surface of the lower abdomen. It is made in a smooth surface but at a certain distance, it is made wavy with strokes. While the coarse texture appears on the surface of the skin or the upper scales. It is made by arranging parts of small and multilevel materials to obtain rough surface.

Besides textures, Liong ornaments on the roof of Tay Kak Sie Temple have different colour arrangements. They have at least seven colours, namely white, light yellow, turquoise, light green, light blue, red, and light brown. White is a neutral colour that covers the surface of the fin bones, the tip of the tail, and the claw nails. The light yellow is a tertiary colour, covering the lower abdominal surface. The turquoise is a tertiary colour, covering the surface of the body scales. The light green is tertiary colour, covering the face on the ornament of northern Liong statue. The light blue is a tertiary colour, covering the face on the ornament of southern Liong statue. Red is the primary colour, covering the nose, tongue, and hair clumps of the foot. The light brown is a tertiary color that covers the horn surface and some bony bulge of the jaw. Monochromatic of blue makes it looks soft and smooth, far from the contrast and sharp impression. As a result, Liong's character on the roof of Tay Kak Sie Temple appears to be clear and more natural.

The ornaments of Liong statue on the roof of Tay Kak Sie Temple contains elements of natural style. Natural elements can be seen at the detail parts of the statues, such as the bulge of the jaw and fin bones, the hair clumps on the tip of the tail, and the surface of the abdomen. The statues also have a dramatic expression on some parts. Body movements tend to be firm and alert to show self-preparedness in every circumstance. These elements become characteristics as well as the differentiation of the Liong statues on the roof of other temples. 
Contribution of Cultural Art in Creating Liong Ornaments on the Roof of Tay Kak Sie Temple

There are several factors differences among Liong ornaments on each temple, including on the roof of Tay Kak Sie Temple. Those factors have contributed to the creation of Liong ornaments on the roof of Tay Kak Sie Temple. The factors include an artist, its culture, its origin (Ming Dynasty), a location, and beliefs.

\section{An artist}

There are two meanings of an artist. The first, an artist means a profession for creating or composing art forms. The second, artist means an individual experienced in the process of creativity or the process of imagination. In this case, the artist means both as a creator of the art, as well as an appreciator (Kartika, 2004: 23).

As a creative work, art is not created easily. To master the skill of making a Liong statue, someone must have some knowledge to process the media of sculpture, to form statues of Liong, and finishing process such as colouring and so on. The skill of making Liong statue can be obtained through the learning process, both formal and informal. In the learning process, it always involves knowledge, theory, and practice. The conformity between theory and practice forms skill attitude. If this skill is already mastered, someone becomes creative which is different between one and another due to the learning process. As a result, the works are also different although they work on the same theme, as it can be seen on the ornament of Liong statue on the roof of Tay Kak Sie Temple.

\section{Culture}

Culture and traditions of China become the foundation of the fine art development for Chinese artists in Indonesia. The foundation is in the form of life values through the Tao teachings. Tao means ways or a clan. The man who follows the Taoist's life is ex- pected to be perfect; capable of distinguishing between good and evil, and beautiful or bad (Hartoko, 1983: 73). For Chinese, Tao is absoluteness that gives existence, life, and peace. The task of the artist, therefore, is to grasp the Taoist's teachings and express them in the form of beautiful artwork or objects (Kartika, 2007: 96).

In creating ornaments of Liong statues, the Chinese artists also applied the foundation of Chinese culture that is Tao's teachings. Usually, before doing this work, they firstly do meditation or pray (Ciak jay), in order to be successful and reach maximum results. Besides the total beauty found in the Taoist teachings, Liong's sculpture must also reflect the moral character $\left.\left(\mathrm{Ch}^{\prime}\right] \mathrm{i}\right)$ of the artist. It refers to the Tri Dharma teachings, namely the practice of $Y i$ and Jen. $Y i$ means working on Liong statue in a good and serious way. Jen means working on a Liong statue based on love, humanity, and tolerance. Furthermore, in terms of colouring, Chinese art uses many monochromatic principles to describe the mood. This principle specifies that each object has an appropriate colour. The colours used in artworks must be a natural suggestion. This principle is called "Sui Lei Fu Ts'ai", which means that the use of colour in Chinese art is not functional but rather symbolic (Kartika, 2007: 98).

The colour of the Liong statue on the roof of Tay Kak Sie Temple has clearly a blue monochromatic element and has no contrasting elements so it looks aligned and smooth. In addition to natural colours, symbolic colours are also used primarily on the surface of scales and faces. The green colour of Liong's face is not a natural (actual) colour, but a symbolic colour that symbolizes immortality, longevity, growth, and prosperity. Likewise, the blue colour on the face Liong of Tay Kak Sie Temple roof symbolizes the gods. 
3. Ming Dynasty

Chinese civilization takes many sources from Taoism or Lao Tze, the teachings given by a philosopher who lived in the fourth century AD. The teachings later became the source of all thoughts of the ancient Chinese nation, as well as in the minds of the artists. Tsu Ding (375-443 AD), a landscape painter argued that art could not be separated from the purity of the soul. There was another figure named Confucius, a philosopher who also lived in the 4th century AD. He argued that an artist should have a clean heart. It then becomes the basis of teachings for artists in the future. Liong figure that often appears in the picture of Chinese society until now is a picture of Liong from Ming Dynasty. There are murmurings in the right and left nostrils, scales more look like fish scales that are composed from the neck to the tail. A pearl, a symbol of true life source and wisdom sometimes appears in the image of Liong.

If it is observed, the manufacture of Liong ornaments, especially on the roof of the temple, will not exactly have the same shape. It is influenced by the belief of Liong. For example, a temple make ornaments of Liong statues that are believed to be able to resist the dangers of fire, then the temple will make ornaments in the type of Chih Wen or Liong on the roof. It differs with the temple that makes Liong ornaments of the Chao Feng which symbolize the fondness of danger (Tatt, 1996: 63).

\section{Location}

The Chinese began to immigrate to the archipelago in the 15th century. Cheng Ho's stopover in Semarang in the fifteenth century was considered as a milestone for the arrival of Chinese into the city. The Chinese arrival had brought their culture, science, knowledge, and etcetera. The Chinese then settled in Semarang in the districts of Pekojan, Jagalan, Petudungan, Gang Warung, Lombok, Kauman, Krajan, Grajen, Wot Gandul, and others.
In contrast to the Chinese arrival in Surakarta and Yogyakarta, it was originated from the riots or Geger Pecinan that occurred in Batavia around 1740. Many Chinese fled to the east, especially to the Kartasura region. This became the entry background of Chinese into Surakarta area (Juwono, 1999: 62). The development of Chinese society in coastal areas such as Semarang City was looser from the rules of the Dutch colonial government. They got better treatment and opened to influence, information, and new things brought by Chinese immigrants or those of other nations. It is inversely proportional to the state of Chinese society in rural areas, such as Surakarta and Yogyakarta, both in terms of livelihood and access to outdoor areas.

The influences gained by the Chinese community living in coastal areas such as Semarang is very diverse, ranging from trade, culture, technology, to arts. The influence of art development in the form of Liong ornament design is more modern, ranging from body shapes, body movements, ornament art styles, Liong ornament colourings, to materials used to create ornaments of Liong statue. While in Surakarta and Yogyakarta, they were considered very isolated from the influence and information from outside, for example, the delivery of construction materials and workers. The easy access to coastal areas compared to other regions made the development of Semarang city on the north coast of Central Java more advanced and developed than of Surakarta and Yogyakarta. It affected the development of temple buildings in coastal and inland areas. The Tay Kak Sie Temple in Semarang built at that time can be interpreted more easily to get raw materials and all kinds of equipment. The ornament of Liong statue on Tay Kak Sie Temple in Semarang, therefore, has more beautiful, more authentic, and more expressive elements of art. 


\section{Beliefs}

Differences of art elements in Liong statue ornaments in Semarang are also influenced by the aspect of belief of Chinese. The Chinese have a high belief in gods and all things with spiritual symbols. Spiritual symbols can be predictions or hunches. This is not only done to overcome problems or obstacles but also to request the god instructions to do something, including in the process of temple improvement. The temple repairment cannot be done heedlessly to avoid undesirable things. No one will be allowed to repair the temple before prayers to the gods, as the "host of the temple", is carried out. If the answer to the prayer has not been obtained then the prayer is done repeatedly with more focus to get answers in the form of instructions to improve the temple. The answer, of course, is not a technical one, but rather in a spiritual form to be applied in the improvement so that the repair process will be done under the blessing or permission from the gods. Through this process, the form, the style, until the colour of Liong statue ornaments on the roof of the temple is finally obtained.

\section{CONCLUSION}

Ornaments of Liong statue on the roof of Tay Kak Sie Temple have three-dimensional works (tri-matra) made with simplification and deformation techniques. The ornaments are imitative forms of Chinese mythology animals. The texture of Liong statue ornaments on the roof of Tay Kak Sie Temple is divided into three parts, namely fine texture on the face, smooth texture on the abdominal section, and rough texture on the scales. The Liong statue ornaments on the roof of Tay Kak Sie Temple use seven colours and contain elements of blue monochromatic colour. Colors seen on Liong statue ornaments on the roof of Tay Kak Sie Temple are light green on his face (left statue ornament) and light blue (right sculpture ornament); red in parts of mouth, tongue, nose; turquoise in body scales from neck to tail; light brown in the horn; light yellow in abdomen; red in clumps of hair on the feet; and white in claw nails and bony bulges on the dorsal fin until the tail.

The style of Liong statue ornaments on the roof of Tay Kak Sie Temple is included into imitative artworks with natural expression style, elongated ornament shape, chest standing upright and head faces the opponent. Liong statue ornaments on the roof of Tay Kak Sie Temple have a very obvious expression of anger, ambition, and firmness. The contribution of art and culture to the creation and distinction of the Liong statue's ornament on the roof of Tay Kak Sie Temple are influenced by the artist's creative abilities, feelings, ideas and experiences based on the teachings of Taoist art; influence of the Ming Dynasty; location of temple; and Chinese belief in spiritual experiences.

\section{End Note}

The research titled Cultural Art Contribution in A Creation of Liong Ornament at the Roof of Tay Kak Sie Temple Semarang Central Java will not be realized without the participation of various parties. The authors, therefore, would like to thank to the main informants: Thio Tiong Gie (a former publicist of Tay Kak Sie Temple), Gan Kok Hwie (a chairman of Makin Semarang), Kwa Tong Hay (a Tay Kak Sie temple publicist); ISI Surakarta, ISBI Bandung, and all parties who have assisted the author in this research.

\section{Bibliography}

Benny Juwono

1999 "Etnik Cina di Surakarta 1890-1927", dalam Lembaran Sejarah, Vol. 2 No. 1, Fakultas Sastra Universitas Gadjah Mada, Yogyakarta. 1-20. 
Dharsono Sony Kartika

2004 Seni Rupa Modern. Bandung: Rekayasa Sains.

Dick Hartoko

1983 Manusia dan Seni. Yogyakarta: Kanisius.

Hari Akbar Yanarko

2012 “Terumbu Karang sebagai Inspirasi Penciptaan Patung Deformatif". Skripsi Program Studi Pendidikan Seni Rupa, Fakultas Bahasa dan Seni, Universitas Negeri Yogyakarta.

Iwan Awaluddin Yusuf

2005 Media, Kematian, dan Identitas Budaya Minoritas:Representasi Etnik Tionghoa dalam Iklan Dukacita. Yogyakarta: UII Press Yogyakarta.

I Wayan Sumantra

2010 “Ekspresi dan Teknik Penciptaan dalam Seni Kriya", dalam Jurnal Institut Seni Indonesia, Denpasar (8 Februari 2010): 1-3.
Mikke Susanto

2011 Diksi Rupa: Kumpulan Istilah $\mathcal{E}$ Gerakan Seni Rupa (edisi revisi). Yogyakarta: DictiArt Lab \& Djagat Art House.

S. Nasution

1996 Metode Penelitian Naturalistik Kualitatif. Bandung: Tarsito.

Tatt, Ong Hean

1996 Simbolisme Hewan Cina. Jakarta: Mega Poin.

The Liang Gie

1983 Filsafat Seni: Sebuah Pengantar. Yogyakarta: Pusat Belajar Ilmu Berguna.

Tiem Penyusun Kamus PPP Bahasa

1988 Kamus Besar Bahasa Indonesia. Jakarta: Balai Pustaka.

Umar Kayam

1981 Seni Tradisi Masyarakat. Jakarta: Sinar Harapan. 